\title{
Burden of Care in Caregivers of Iranian patients with chronic disorders: a systematic review and meta-analysis
}

\author{
Hayedeh Rezaei ${ }^{1}$, Seyed Hassan Niksima ${ }^{2}$ and Reza Ghanei Gheshlagh ${ }^{3^{*}}$ (D)
}

\begin{abstract}
Introduction: Caring for patients with chronic disorders can lead to different problems for caregivers in physical, psychological, social, family, and financial domains. High levels of burden of care can make caregivers vulnerable to physical and psychological conditions and influence their quality of life. Therefore, the goal of the present study was to estimate the overall percentage of burden of care in caregivers of Iranian patients with chronic disorders.

Methods: A total of 25 articles published from inception to February 2019 were reviewed. Search for articles was conducted in international (Scopus, Web of Science, and PubMed) and domestic (Scientific Information Database (SID) and Maglran) databases, using the following keywords: "Caregiver," "Burden," and "Iran," and their possible combinations. The data were analyzed using the meta-analysis method and the random effects model. All the analyses were performed using STATA, version 14.

Results: The overall percentage of burden of care in caregivers of Iranian patients with chronic disorders was 53.28\% (95\% Cl: 46.13-60.43). The highest percentage of burden of care was related to dialysis $(62.75 ; 95 \% \mathrm{Cl}$ : 56.11-69.38), mental disorders (58.69; 95\% Cl: 49.70-67.69), and Alzheimer's disease (57.07; 95\% Cl: 46.23-67.92), respectively; and the lowest percentage of burden of care was related to diabetes (34.92; 95\% Cl: 18.01-51.82).

Conclusions: Caregivers of Iranian patients with chronic disorders experience high levels of burden of care, especially those caring for patients undergoing dialysis, patients with mental disorders, and patients with Alzheimer's disease. Therefore, necessary measures need to be taken by Iranian health care officials to reduce burden of care in caregivers.
\end{abstract}

Keywords: Burden of care, Caregiver, Chronic disorder, Systematic review, Iran

\section{Introduction}

Chronic disorders are the main cause of mortality around the world, so that they account for $60 \%$ of deaths globally [1]. Chronic disorders threaten and alter patients' well-being; independence; body integrity; family, social, and professional roles; personal goals and plans for the future; and economic stability [2]. In most cases,

\footnotetext{
* Correspondence: Rezaghanei30@yahoo.com; Rezaghanei30@gmail.com ${ }^{3}$ Spiritual Health Research Center, Research Institute for Health Development, Kurdistan University of Medical Sciences, Sanandaj, Iran

Full list of author information is available at the end of the article
}

it is family members who take care of patients [3], therefore, the treatment of chronic disorders and taking care of chronic patients has transferred into homes [4]. Taking care of a patient can affect all aspects of the caregiver's life and lead to multiple mental, emotional, physical, and financial challenges for them [5]. In addition, caregiving can lead to social isolation, life dissatisfaction, reduced quality of life, and reduced physical health in caregivers [6-9], and make them vulnerable to depression, anxiety, and stress [10]. The more demands placed on the caregiver by the patient, the more challenges

(c) The Author(s). 2020 Open Access This article is licensed under a Creative Commons Attribution 4.0 International License, which permits use, sharing, adaptation, distribution and reproduction in any medium or format, as long as you give appropriate credit to the original author(s) and the source, provide a link to the Creative Commons licence, and indicate if changes were made. The images or other third party material in this article are included in the article's Creative Commons licence, unless indicated otherwise in a credit line to the material. If material is not included in the article's Creative Commons licence and your intended use is not permitted by statutory regulation or exceeds the permitted use, you will need to obtain permission directly from the copyright holder. To view a copy of this licence, visit http://creativecommons.org/licenses/by/4.0/. The Creative Commons Public Domain Dedication waiver (http://creativecommons.org/publicdomain/zero/1.0/) applies to the data made available in this article, unless otherwise stated in a credit line to the data. 
the caregiver experiences [11]. In addition to mental problems, caregiving can lead to physical problems, including gastric ulcers, back injuries, headaches, arthritis, and high blood pressure [12]. Therefore, caregivers are sometimes called hidden patients [13]. A previous study found higher mortality rates (by 63\%) in caregivers experiencing caregiver strain than other caregivers [14].

Burden of care refers to physical, mental, social, or financial reactions by the caregiver during caregiving shown as a result of an imbalance between patient's needs and health services [15]. This lack of balance is related to caregivers' multiple roles, physical and mental condition, and financial status; and quality of governmental health services. It also has the following consequences: impairment in daily and leisure activities and social interactions, disablement and illness, isolation from family and losing family relationships, losing hope in social support, inadequate care received by the patient, vulnerability to chronic disorders, and abandoning the patient [16]. Caregivers have to maintain a balance between their own needs and those of their patients. They experience a high level of stress due to lack of adequate training on caregiving and limited resources [17, 18*, 19*]. On the other hand, because they spend most of their time with patients, they tend to forget their own needs and this may alter their lifestyle $\left[20,21^{*}, 22\right]$.

Goldzweig et al. showed that caregivers of cancer patients experienced high levels of burden of care and low levels of social support and lacked the skill to adjust to high levels of burden of care [23]. Burden of care is directly related to patients' needs [13]. Another study found that caregivers with lower education and income levels reported higher levels of burden of care [24]. In Iran, like other developing countries, due to an imbalance between the number of patients and that of health care providers, caregivers are responsible to take care of their patients, and this imposes high levels of physical, mental, social, emotional, and financial burden on them; determining the level of burden of care can highlight this issue properly. Therefore, the goal of the present study is to estimate the percentage of burden of care in caregivers of chronic patients in Iran.

\section{Methods}

In this systematic review and meta-analysis, the percentage of burden of care in caregivers of Iranian patients with chronic disorders was reviewed and reported according to the steps of the PRISMA statement [25]. Based on the PICO, Population (P) includes articles focused on burden of care in caregivers of Iranian patients with chronic disorders, and Outcome $(\mathrm{O})$ is the burden of care raw score. Intervention (I) and Comparison (C) are not applicable.

\section{Search strategy}

To find related articles, two researchers independently searched the following national and international scientific databases until February 2019: SID, MagIran, Google Scholar, Web of Science, PubMed, and Scopus. Search for articles, screening the articles, methodological quality examination, and data extraction were all conducted by two independent researchers, and any disagreement between them was resolved by a third author experienced in this matter.

The reference lists of articles were also reviewed in order to find more related articles. Keywords of "burden, " "Caregiver," "Iran," and their possible combinations were used to search for articles. In the first step, all articles containing the above keywords were collected. In order not miss any article names of chronic disorders (e.g. diabetes, stroke, heart disease, Alzheimer's disease, mental disorders, cancer, social cord injury, thalassemia etc.) were used along with the aforementioned keywords.

\section{Selection of studies and data extraction}

Articles with the following criteria were included in the study: observational (non-interventional) studies, published in Farsi or English, providing enough information related to the study objectives, referring to name of a chronic disorder in title, and reporting the burden of care raw score. On the other hand, articles with the following criteria were excluded from the study: lacking sufficient information, not presenting new results (repeated studies), and unavailable full texts. According to the aforementioned criteria, abstracts were reviewed by the researchers and the related ones were selected. The data was extracted and managed in a pre-designed form in Microsoft Excel. Then, a form assessing name of the first author, publication year, study participants, sample size, measuring instruments, location of research, and burden of care standardized score was used to assess article characteristics.

\section{Transformation of scale scores}

In the next step, each raw score was transferred to a 0 100 scale using the following formula:

Transformed Scale $=\left[\frac{(\text { Actual raw score })-(\text { lowest possible raw score })}{\text { possible raw score range }}\right] \times 100$

In the formula shown above, "Actual raw score" is the raw values obtained by summation, "lowest possible raw score" is the lowest raw value possible, and "possible raw score range" is the difference between the maximum and minimum possible raw scores [26].

The three following instruments were used to assess burden of care in the selected studies:

The Caregiver Burden Inventory (CBI): This 24-item questionnaire was designed by Novak and Guest in 1989 to assess objective and subjective burden of care. It has 5 subscales, including physical, developmental, emotional, social, and time-dependence burden. Items are rated on a 5 -point Likert-type scale ranging from 1 (totally incorrect) 
to 5 (totally correct). Total score ranges from 24 to 120 , and higher scores indicate higher burden of care [27].

The Zarit Caregiver Burden Interview (ZBI): This interview was developed by Zarit et al. It has 22 items assessing personal, social, emotional, and financial pressures. The items are rated on a 5-point Likert-type scale ranging from 0 (always) to 4 (nearly always). Total score rages from 0 to 88 , and higher scores show greater burden of care [28].

The Modified Caregiver Strain Index (MCSI): This was developed by Mohammadi (2006) based on the index developed by Robinson. It has 13 items assessing burden of care in caregivers of patients with Alzheimer's disease. The items are rated on a 4-point Likert-type scale ranging from 1 (little) to 4 (very much). Total score ranges from 13 to 52, and higher scores indicate greater burden of care $\left[29^{*}\right]$.

\section{Quality assessment}

Methodological quality of the papers was investigated based on the ten selected items from the STROBE (Strengthening The Reporting of OBservational Studies in Epidemiology) checklist (title and abstract, objectives and hypotheses, research context, entry criteria, sample size, statistical methods, descriptive data, interpretation of findings, research limitations and funding) [30]. Based on the methodological quality score, articles are categorized as follows: weak (score 0-4), average (score 5-7), and strong (score 8-10). Articles with low methodological quality were excluded from the analysis. More information on methodological quality is provided in Table 1.

\section{Statistical analyses}

Since the burden of are score had a normal distribution, variance of each study was calculated based on the

Table 1 The methodological quality based on STROBE

\begin{tabular}{|c|c|c|c|c|c|c|c|c|c|c|c|}
\hline First Author & $\begin{array}{l}\text { Title \& } \\
\text { abstract }\end{array}$ & $\begin{array}{l}\text { Objectives and } \\
\text { hypotheses }\end{array}$ & $\begin{array}{l}\text { Research } \\
\text { setting }\end{array}$ & $\begin{array}{l}\text { Inclusion } \\
\text { criteria }\end{array}$ & $\begin{array}{l}\text { Sample } \\
\text { size }\end{array}$ & $\begin{array}{l}\text { Statistical } \\
\text { methods }\end{array}$ & $\begin{array}{l}\text { Descriptive } \\
\text { data }\end{array}$ & $\begin{array}{l}\text { Analysis of } \\
\text { findings }\end{array}$ & Limitations & Funding & Score \\
\hline Asadi [31*] & + & + & + & + & + & + & + & + & - & + & 9 \\
\hline Azimi Lolaty [32*] & + & + & + & + & + & + & + & + & - & - & 8 \\
\hline Adili [33*] & + & + & + & + & + & + & + & + & - & - & 8 \\
\hline Jafari $\left[34^{*}\right]$ & + & + & + & + & + & + & + & + & + & + & 10 \\
\hline $\begin{array}{l}\text { Hassanzadeh } \\
{\left[35^{*}\right]}\end{array}$ & + & + & + & + & + & + & - & + & + & + & 9 \\
\hline $\begin{array}{l}\text { Rahimi Naderi } \\
{\left[36^{*}\right]}\end{array}$ & + & + & + & + & + & + & + & + & - & + & 9 \\
\hline Mirsoleimani [37*] & + & + & + & + & + & + & + & + & - & + & 9 \\
\hline $\begin{array}{l}\text { Torabi Chafjiri } \\
{\left[38^{*}\right]}\end{array}$ & + & + & + & + & + & + & + & + & - & + & 9 \\
\hline Safaeian [39*] & + & + & + & + & + & + & + & + & _- & + & 9 \\
\hline Khazaeipour [40*] & + & + & + & + & + & + & + & + & + & - & 9 \\
\hline Bamari $\left[41^{*}\right]$ & + & + & + & + & + & + & + & + & - & - & 8 \\
\hline Vahidi $\left[42^{*}\right]$ & + & + & + & + & + & + & + & + & - & - & 8 \\
\hline Talebi [18] & + & + & + & + & + & + & + & + & - & + & 9 \\
\hline Haghgoo $\left[43^{*}\right]$ & + & + & + & + & + & + & + & + & - & - & 8 \\
\hline Hosseini $\left[44^{*}\right]$ & + & + & + & + & + & + & + & + & - & + & 9 \\
\hline Mashayekhi [21] & + & + & + & - & + & + & + & + & - & + & 8 \\
\hline Shamsaei $\left[45^{*}\right]$ & + & + & + & + & + & + & + & + & + & + & 10 \\
\hline Mashayekhi [46*] & + & + & + & + & + & + & + & + & - & - & 8 \\
\hline Garmabi [47*] & + & + & + & + & + & + & + & + & - & - & 8 \\
\hline Salmani [19*] & + & + & + & + & + & + & + & + & + & - & 9 \\
\hline Abbasi $\left[48^{*}\right]$ & + & + & + & + & + & + & + & + & + & + & 10 \\
\hline $\begin{array}{l}\text { Abdollahpour } \\
{\left[49^{*}\right]}\end{array}$ & + & - & + & + & + & + & + & + & + & - & 8 \\
\hline Haresabadi $\left[50^{*}\right]$ & + & + & + & + & + & + & + & + & + & + & 10 \\
\hline Navidian $\left[51^{*}\right]$ & + & + & + & + & + & + & + & + & - & - & 8 \\
\hline $\begin{array}{l}\text { Mohammadi } \\
\text { Shahbalagy [29*] }\end{array}$ & + & + & + & + & + & - & + & + & - & - & 8 \\
\hline
\end{tabular}


normal distribution, as $\operatorname{var}(\bar{X})=\sigma^{2} /_{n}$. The weight of each study was inversely proportional to the variance. The burden of care mean score was evaluated with a 95\% confidence interval. The $\mathrm{I}^{2}$ statistic and the Cochran $\mathrm{Q}$ test were used to assess heterogeneity among the data. For $\mathrm{I}^{2}$ statistics greater than $50 \%$ or Cochran $\mathrm{Q}$ test probability values less than $0.05(P<0.05)$, the random effects model was used [52]. Otherwise, the fixed effects model was used. The sensitivity analysis was used to determine the role of each study in the final result. This was done by removing the studies one at a time, and assessing the impact of removing each study on the final results. A meta-regression model was employed to assess the relation between burden of care scores and mean age of participants, year of publication, and sample size. Publication bias was inspected visually with funnel plots [53] and analyzed with Egger's method [54]. The data was analyzed using the Stata software, version 14. The significance level was set at 0.05 .

\section{Results}

According to the first step of the PRISMA guidelines, in the stage of identification, 97 articles were retrieved from domestic and international databases. In the screening stage, abstracts were examined, and 66 articles with unrelated subjects were discarded. In the stage of eligibility examination, another 6 articles were discarded based on the inclusion and exclusion criteria. Finally, a total of 25 articles were included in the analysis. The process of searching for, selecting, and screening articles is shown in Fig. 1.

From the selected articles, 12 were in English and 13 in Farsi. More information on year of publication, type of chronic disorders, instruments to measure burden of care, burden of care standard score, methodological quality, and demographic description of participants is shown in Table 2. Quality score refers to the methodological quality of studies. This score is calculated based on the 10 aforementioned items and total methodological quality score ranges from 0 to 10 . Higher scores indicate greater methodological quality.

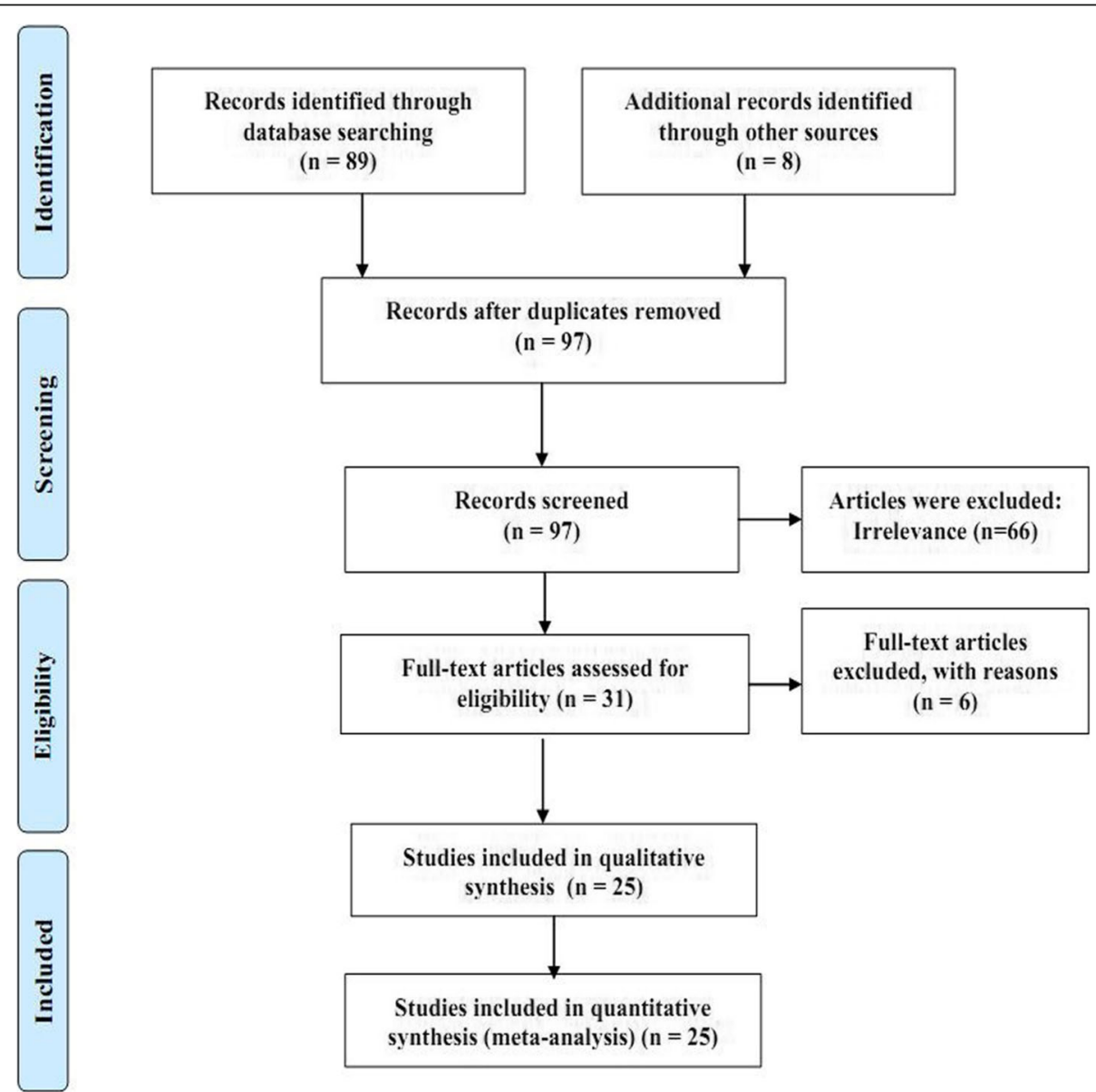

Fig. 1 Article selection and screening flowchart 
Table 2 Details of selected articles

\begin{tabular}{|c|c|c|c|c|c|c|}
\hline First Author & Year & $\begin{array}{l}\text { Sample } \\
\text { size }\end{array}$ & $\begin{array}{l}\text { Type of } \\
\text { patients }\end{array}$ & Scale & $\begin{array}{l}\text { Burden of } \\
\text { care }(\%)\end{array}$ & Subject Description \\
\hline Asadi $\left[31^{*}\right]$ & 2018 & 152 & Psychology & ZARIT & 35.21 & $\begin{array}{l}\text { Gender of the caregivers: } 98 \text { men and } 54 \text { women } \\
50 \% \text { of the caregivers were } 30-50 \text { years old. } \\
97 \% \text { of the caregivers were married. } \\
60.6 \% \text { of the caregivers had a high school diploma or a lower education level. }\end{array}$ \\
\hline $\begin{array}{l}\text { Azimi Lolaty } \\
{\left[32^{*}\right]}\end{array}$ & 2018 & 200 & Psychology & ZARIT & 64.77 & $\begin{array}{l}\text { Gender of the caregivers: } 104 \text { men and } 96 \text { men } \\
\text { Mean age of the caregivers: } 51.2 \pm 12.9 \text { years } \\
57.4 \% \text { of the caregivers were } 40-59 \text { years old. } \\
48.5 \% \text { of the caregivers were children of patients. }\end{array}$ \\
\hline Adili $\left[33^{*}\right]$ & 2018 & 116 & Cancer & $\mathrm{CBI}$ & 18.25 & $\begin{array}{l}\text { Mean age of the patients: } 46 \pm 11 \text { years } \\
\text { Mean age of the caregivers: } 48 \pm 10 \text { years } \\
85 \% \text { of the caregivers were wives of husbands of patients. } \\
57 \% \text { of the caregivers had a high school diploma or a lower education level. }\end{array}$ \\
\hline Jafari $\left[34^{*}\right]$ & 2018 & 246 & Dialysis & $\mathrm{CBI}$ & 67.5 & $\begin{array}{l}\text { Gender of the patients: ( } 129 \text { men and } 116 \text { women) } \\
\text { Mean age of the patients: } 58.6 \pm 15 \text { years } \\
\text { Duration of receiving hemodialysis: } 4.12 \pm 3.74 \text { years } \\
\text { Gender of the caregivers: } 146 \text { ( } 165 \text { women and } 81 \text { men) } \\
\text { Mean age of the caregivers: } 42 \pm 15 \text { years } \\
\text { Marital status, job, and education of the caregivers: } 153 \text { (62.2\%) married, } 133 \\
\text { (53.9\%) housewives, and } 118 \text { (48.1\%) with a high school diploma }\end{array}$ \\
\hline $\begin{array}{l}\text { Hassanzadeh } \\
{\left[35^{*}\right]}\end{array}$ & 2017 & 200 & $\begin{array}{l}\text { Psychological } \\
\text { problems }\end{array}$ & $\mathrm{CBI}$ & 52.86 & $\begin{array}{l}\text { Gender of the patients: } 91 \text { women and } 109 \text { men } \\
\text { Most of the patients (43\%) were 11-15 years old. } \\
\text { Gender of the caregivers: } 87 \text { men and } 113 \text { women }\end{array}$ \\
\hline $\begin{array}{l}\text { Rahimi Naderi } \\
{\left[36^{*}\right]}\end{array}$ & 2017 & 129 & Diabetes & $\mathrm{CBI}$ & 26.85 & $\begin{array}{l}\text { Mean age of the caregivers: } 39 \pm 12 \text { years } \\
\text { Gender of the caregivers: } 101 \text { women and } 28 \text { men } \\
31.8 \% \text { of the caregivers were daughters of patients. } \\
77.5 \% \text { of the caregivers were married. }\end{array}$ \\
\hline $\begin{array}{l}\text { Mirsoleimani } \\
{\left[37^{*}\right]}\end{array}$ & 2017 & 104 & Cancer & $\mathrm{CBI}$ & 38.45 & $\begin{array}{l}\text { Gender of the patients: ( } 33 \text { men and } 71 \text { women) } \\
\text { Gender of the caregivers: ( } 46 \text { men and } 58 \text { women) } \\
64(61.5 \%) \text { the patients had breast cancer. } \\
50(48.1 \%) \text { the caregivers were children of patients. } \\
\text { Most of the caregivers ( } 50 \%) \text { were } 25-44 \text { years old, and most of the patients } \\
(47.1 \%) \text { were } 45-64 \text { years old. }\end{array}$ \\
\hline $\begin{array}{l}\text { Torabi Chafjiri } \\
{\left[38^{*}\right]}\end{array}$ & 2017 & 407 & Stroke & $\mathrm{CBI}$ & 29.16 & $\begin{array}{l}\text { Gender of the caregivers: } 362 \text { women and } 45 \text { men } \\
\text { Mean age of the caregivers: } 38.3 \pm 8.8 \text { years } \\
\text { Mean duration of caregiving: } 4.2 \pm 2.5 \text { years } \\
\text { Most of the caregivers ( } 65.6 \%) \text { were housewives. } \\
96.6 \% \text { of the caregivers had a high school diploma or a lower education level. }\end{array}$ \\
\hline Safaeian [39*] & 2017 & 100 & Cancer & $\mathrm{CBI}$ & 77.56 & $\begin{array}{l}\text { Gender of the patients: } 55 \text { women and } 45 \text { men } \\
\text { Mean age of the caregivers: } 38.1 \pm 12.5 \text { years } \\
\text { Gender of the caregivers: } 58 \text { women and } 42 \text { men } \\
64 \% \text { of the caregivers were children of patients. } \\
43 \% \text { of the caregivers had primary school education. }\end{array}$ \\
\hline $\begin{array}{l}\text { Khazaeipour } \\
{\left[40^{*}\right]}\end{array}$ & 2017 & 163 & $\mathrm{SCl}$ & ZARIT & 44.20 & $\begin{array}{l}\text { Mean age of the patients: } 36 \pm 12.5 \text { years } \\
\text { Gender of the patients: } 32 \text { women and } 131 \text { men } \\
\text { Duration of suffering from the illness: } 76.5 \pm 79 \text { months } \\
\text { Marital status of the patients: } 56.5 \% \text { married, } 38 \% \text { single, and } 5.5 \% \text { divorced } \\
\text { Mean age of the caregivers: } 38.1 \pm 13.2 \text { years } \\
\text { Duration of caregiving: } 69.4 \pm 73.1 \text { months } \\
\text { Gender of the caregivers: } 61 \text { men and } 102 \text { women }\end{array}$ \\
\hline Bamari $\left[41^{*}\right]$ & 2016 & 70 & Diabetes & ZARIT & 44.14 & $\begin{array}{l}\text { Gender of the patients: } 40 \text { women and } 30 \text { men } \\
\text { Gender of the caregivers: } 36 \text { women and } 34 \text { men } \\
70 \% \text { of the caregivers were wives or husbands of patients. }\end{array}$ \\
\hline Vahidi $\left[42^{*}\right]$ & 2016 & 150 & Cancer & ZARIT & 34.71 & $\begin{array}{l}\text { Gender of the caregivers: } 73 \text { women and } 77 \text { men } \\
\text { Mean age of the caregivers: } 39.6 \pm 13.8 \text { years } \\
34.7 \% \text { of the caregivers were wives or husbands of patients. }\end{array}$ \\
\hline Talebi [18] & 2016 & 154 & Dialysis & ZARIT & 57.67 & $\begin{array}{l}\text { Mean age of the patients: } 60.9 \text { years } \\
\text { Mean age of the caregivers: } 43.7 \text { years } \\
\text { Duration of receiving hemodialysis: } 43.2 \text { months } \\
\text { Most of the caregivers had a high school diploma or a lower education level } \\
(51.3 \%) \text { and were married }(82.5 \%) \text {. } \\
49.4 \% \text { of the caregivers were children of patients. }\end{array}$ \\
\hline
\end{tabular}


Table 2 Details of selected articles (Continued)

\begin{tabular}{|c|c|c|c|c|c|c|}
\hline First Author & Year & $\begin{array}{l}\text { Sample } \\
\text { size }\end{array}$ & $\begin{array}{l}\text { Type of } \\
\text { patients }\end{array}$ & Scale & $\begin{array}{l}\text { Burden of } \\
\text { care (\%) }\end{array}$ & Subject Description \\
\hline Haghgoo $\left[43^{*}\right]$ & 2016 & 246 & Psychology & $\mathrm{CBI}$ & 74.19 & $\begin{array}{l}\text { Mean age of the caregivers: } 34.5 \pm 13.7 \text { years } \\
\text { Gender of the caregivers: } 115 \text { men and } 131 \text { women } \\
\text { Marital status of the caregivers: } 107 \text { single, } 127 \text { married, and } 12 \text { divorced. }\end{array}$ \\
\hline Hosseini $\left[44^{*}\right]$ & 2015 & 150 & $\begin{array}{l}\text { Alzheimer's } \\
\text { disease }\end{array}$ & MCSI & 61.97 & $\begin{array}{l}\text { Mean age of the caregivers: } 46.7 \pm 10 \text { years } \\
75.3 \% \text { of the caregivers were married and } 65.3 \% \text { had a high school diploma. } \\
66 \% \text { of caregivers were daughters of patients }\end{array}$ \\
\hline Mashayekhi [21] & 2015 & 51 & Dialysis & ZARIT & 61.3 & $\begin{array}{l}\text { Mean age of the patients: } 53 \pm 17.9 \text { years } \\
\text { Gender of the patients: } 22 \text { women and } 29 \text { men } \\
\text { Mean age of the caregivers: } 42.1 \pm 14.7 \text { years } \\
\text { Gender of the caregivers: } 35 \text { women and } 16 \text { men } \\
\text { Most of the caregivers were married (86.3\%) and illiterate (51\%). }\end{array}$ \\
\hline Shamsaei $\left[45^{*}\right]$ & 2015 & 225 & Psychology & ZARIT & 58.78 & $\begin{array}{l}\text { Number of patients: } 121 \text { men and } 104 \text { women } \\
\text { Number of caregivers: } 59 \text { men and } 166 \text { women } \\
\text { Duration of suffering from the illness: } 9.8 \pm 6.7 \text { years } \\
70.7 \% \text { of the caregivers were married and } 45.3 \% \text { had a high school diploma. } \\
\text { Most of the patients ( } 32.4 \% \text { ) were } 40-50 \text { years old, and most of the caregivers } \\
\text { (28.4\%) were } 50-60 \text { years old, }\end{array}$ \\
\hline $\begin{array}{l}\text { Mashayekhi } \\
{\left[46^{*}\right]}\end{array}$ & 2014 & 175 & Thalassemia & ZARIT & 49.88 & $\begin{array}{l}\text { Mean age of the caregivers: } 38.1 \pm 9.3 \text { years } \\
\text { Mean age of the patients: } 10.7 \pm 4.8 \text { years } \\
\text { All of the caregivers were mothers of patients. }\end{array}$ \\
\hline Garmabi $\left[47^{*}\right]$ & 2014 & 123 & Psychology & $\mathrm{CBI}$ & 75.59 & Demographic characteristics of patients and caregivers not reported. \\
\hline Salmani $\left[19^{*}\right]$ & 2014 & 60 & Cancer & $\mathrm{CBI}$ & 84.82 & $\begin{array}{l}\text { Mean age of the patients: } 38.4 \pm 9 \text { years } \\
\text { Mean age of the caregivers: } 43.6 \pm 19.6 \text { years } \\
\text { Duration of suffering from the illness: } 17.7 \pm 16.2 \text { months } \\
\text { Gender of the caregivers: } 49 \text { women and } 11 \text { men } \\
\text { Most of the caregivers (50\%) were children of patients. }\end{array}$ \\
\hline Abbasi $\left[48^{*}\right]$ & 2013 & 133 & Cancer & $\mathrm{CBI}$ & 57.60 & $\begin{array}{l}\text { Gender of the caregivers: } 67 \text { women and } 66 \text { men } \\
\text { Mean age of the caregivers: } 35.7 \pm 14.3 \text { years } \\
\text { Duration of suffering from the illness: } 16.5 \pm 19.5 \text { months } \\
\text { Most of the caregivers }(51.9 \%) \text { were children of patients. } \\
\text { Most of the patients }(28.6 \%) \text { had breast cancer. } \\
\text { Most of the caregivers }(62.4 \%) \text { were married. }\end{array}$ \\
\hline $\begin{array}{l}\text { Abdollahpour } \\
{\left[49^{*}\right]}\end{array}$ & 2012 & 153 & Psychology & $\mathrm{CBI}$ & 47.58 & $\begin{array}{l}\text { Gender of the patients: } 90 \text { women and } 63 \text { men } \\
\text { Mean age of the patients: } 77.1 \pm 7.4 \text { years } \\
\text { Mean age of the caregivers: } 53 \pm 13 \text { years } \\
88 \text { of the caregivers were children of patients ( } 69 \text { were daughters and } 19 \text { were } \\
\text { sons of patients). }\end{array}$ \\
\hline Haresabadi $\left[50^{*}\right]$ & 2012 & 75 & Psychology & ZARIT & 71.13 & $\begin{array}{l}\text { Mean age of the patients: } 34.8 \pm 12.2 \text { years } \\
\text { Gender of the patients: } 43 \text { men and } 32 \text { women } \\
\text { Duration of suffering from the illness: } 6.2 \pm 6.3 \text { years } \\
\text { Mean age of the caregivers: } 40.1 \pm 12.2 \text { years } \\
\text { Gender of the caregivers: } 35 \text { men and } 40 \text { women }\end{array}$ \\
\hline Navidian $\left[51^{*}\right]$ & 2008 & 125 & Psychology & ZARIT & 47.9 & $\begin{array}{l}\text { Gender of the patients: } 83 \text { men and } 42 \text { women } \\
59.2 \% \text { of the patients were } 20-35 \text { years old. } \\
\text { Gender of the caregivers: } 59 \text { men and } 66 \text { women } \\
52 \% \text { of the caregivers were } 20-35 \text { years old. }\end{array}$ \\
\hline $\begin{array}{l}\text { Mohammadi } \\
\text { Shahbalagy }\left[29^{*}\right]\end{array}$ & 2006 & 81 & $\begin{array}{l}\text { Alzheimer's } \\
\text { disease }\end{array}$ & MCSI & 50.82 & $\begin{array}{l}\text { Gender of the caregivers: } 49 \text { women and } 32 \text { men } \\
56 \% \text { of the caregivers were wives or husbands of patients. }\end{array}$ \\
\hline
\end{tabular}

All of the selected articles had average methodological quality. In the study, 25 articles with a total sample size of 3806 (on average, 152 participants per study) were reviewed systematically. The percentage of burden of care in caregivers of chronic patients was found to be 53.28\% (95\% CI: 46.13-60.43). The highest (84.82) and lowest (18.25) burden of care scores had been reported by Salmani [19*] and Adili [33*], respectively (Fig. 2).
The highest burden of care scores (\%) belonged to caregivers of patients undergoing dialysis $(62.75$; $95 \%$ CI: 56.11-69.38), patients with mental disorders (58.69; 95\% CI: 49.7-67.69), and patients with Alzheimer's disease (57.07; 95\% CI: 46.23-67.92). On the other hand, the lowest burden of care score (\%) was associated with diabetes (34.92; 95\% CI: $18.01-$ 51.82). 


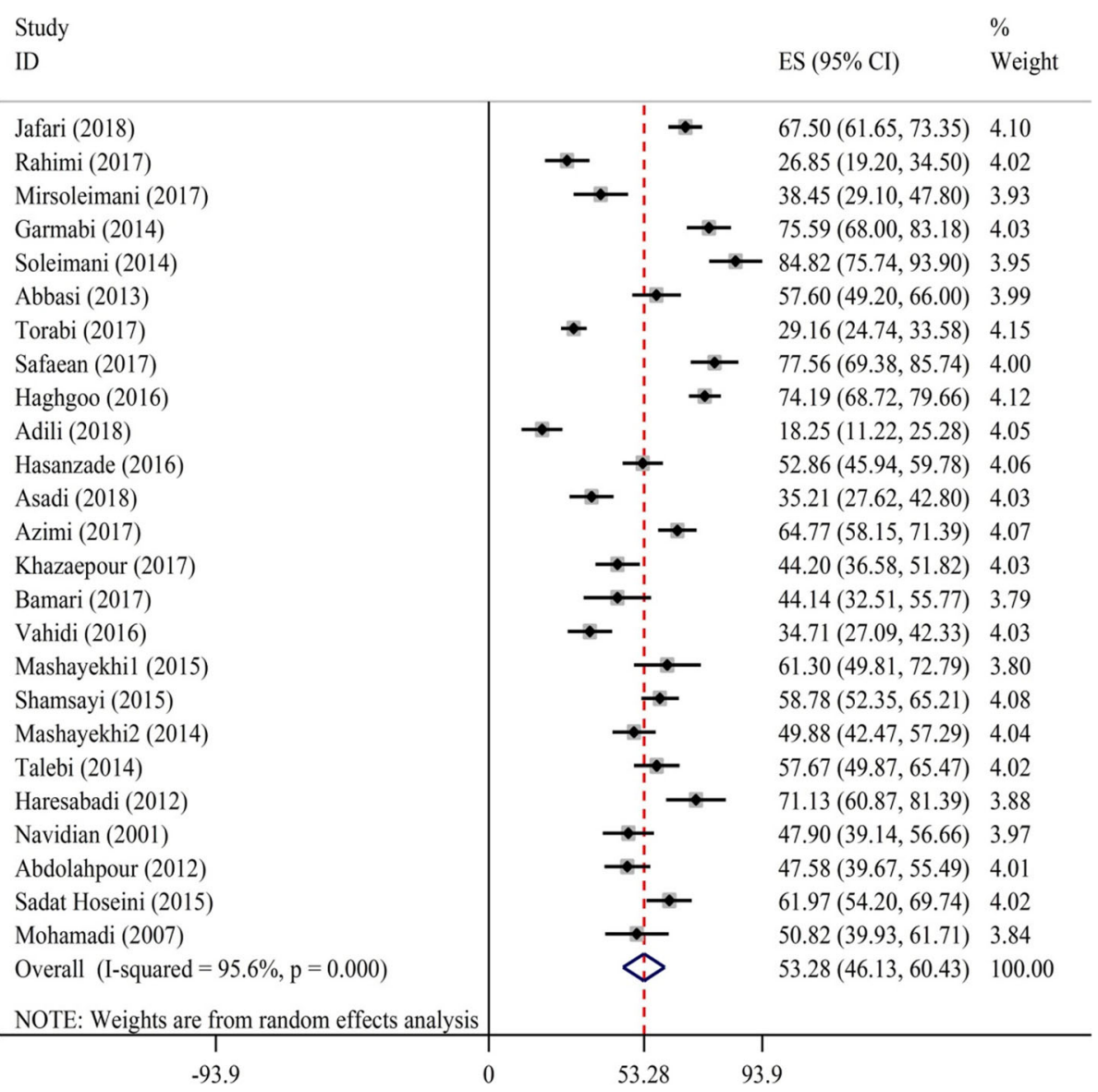

Fig. 2 Burden-of-care scores for chronic patients based on the first author and year of study. The middle point in each line represents the standardized score for Iranian chronic patients; also, the diamond shows the overall score for all studies

Result of subgroup analysis by instrument (the CBI, the ZARIT etc.) showed that the highest burden of care was reported in studies using the CBI $(54.96$; 95\% CI: 39.52-70.39). The highest and the lowest burden of care were related to the provinces located in regions 2 and 3, respectively. More details on burden of care scores (\%) for different disorders, geographical areas, and tools are provided in Table 3.

As shown in Fig. 3, the meta-regression results indicated no significant correlation between the mean burden of care score and year of publication $(p=0.507)$ and sample size $(p=0.407)$ (Fig. 3). Sensitivity analysis showed that none of the studies alone had a significant effect on the overall estimation of the total percentage of burden of care. Moreover, as shown in Fig. 4, publication bias was not significant ( $p=0.84)$ (Fig. 4$)$.

\section{Discussions}

The present study was aimed at estimating the overall percentage of burden of care in caregivers of Iranian patients with chronic disorders. The burden of care scores indicated that the caregivers experienced high levels of burden of care. The findings of this research are in line with those reported in the international literature. For example, Etters et al. reported a high burden of care in caregivers of patients with mental disorders [55]. Also, Bayoumi et al. reported a higherthan-average burden of care in caregivers of dialysis patients (20.1\%) [56]. These results agree with the current research. In the present study, the highest level of burden of care was observed in caregivers of hemodialysis patients. Consistent with this finding, Mollaoğlu showed that caring for a hemodialysis patient is very stressful and has an adverse impact on physical, psychological, and mental wellbeing of caregivers (59.2\%) [57].

The adverse health effects of Uremia affect all organs of the body and lead to impairments and lowered quality of life. The impact of dialysis on the life of patients and their families is so deep that may lead to adjustment problems, and inevitably increase the burden of the care for the caregiver [58]. Caregivers of patients with mental disorders face issues, such as interpersonal problems, role conflicts, stress, and constant anxiety in life, thereby 
Table 3 Burden-of-care scores for different disorder subgroups, areas and tools

\begin{tabular}{|c|c|c|c|c|c|c|c|}
\hline \multirow[t]{2}{*}{ Groups } & & \multirow{2}{*}{$\begin{array}{l}\text { Number } \\
\text { of } \\
\text { Studies }\end{array}$} & \multirow{2}{*}{$\begin{array}{l}\text { Sample } \\
\text { Size }\end{array}$} & \multirow{2}{*}{$\begin{array}{l}\text { Score } \\
(\%)\end{array}$} & \multirow[t]{2}{*}{$95 \% \mathrm{Cl}$} & \multicolumn{2}{|c|}{ Heterogeneity } \\
\hline & & & & & & 12 & $P$ \\
\hline \multirow[t]{6}{*}{ Type of disease } & Hemodialysis & 3 & 469 & 62.75 & $56.11-69.38$ & 51 & 0.130 \\
\hline & Diabetes & 2 & 199 & 34.99 & $18.01-51.82$ & 83.1 & 0.015 \\
\hline & Cancer & 6 & 663 & 51.84 & $30.55-73.13$ & 97.5 & 0.001 \\
\hline & Mental Disorder & 9 & 1499 & 58.69 & $49.70-67.69$ & 92.8 & 0.001 \\
\hline & Alzheimer's & 2 & 231 & 57.07 & $46.23-67.92$ & 62.5 & 0.102 \\
\hline & Others & 3 & 745 & 40.81 & $27.23-54.40$ & 92.6 & 0.001 \\
\hline \multirow[t]{5}{*}{ Country Areas } & 1 & 10 & 1423 & 51.23 & $40.76-61.70$ & 94.4 & 0.001 \\
\hline & 2 & 1 & 246 & 74.19 & $68.72-79.66$ & - & - \\
\hline & 3 & 3 & 711 & 40.31 & $23.72-56.91$ & 94.9 & 0.001 \\
\hline & 4 & 4 & 753 & 47.21 & $28.44-65.97$ & 94.9 & 0.001 \\
\hline & 5 & 7 & 674 & 62.47 & $50.43-74.51$ & 91.5 & 0.001 \\
\hline \multirow[t]{3}{*}{ Tool } & $\mathrm{CBI}$ & 10 & 1664 & 54.96 & 39.52-70.39 & 98 & 0.001 \\
\hline & Zarit & 11 & 1558 & 51.69 & $44.67-58.70$ & 87.7 & 0.001 \\
\hline & Others & 4 & 584 & 53.50 & $47.25-59.76$ & 57 & 0.073 \\
\hline
\end{tabular}

Area 1: Provinces of Tehran, Alborz, Qazvin, Mazandaran, Semnan, Golestan, and Qom; Area 2: Provinces of Esfahan, Fars, Boushehr, Chaharmahal Bakhtiari, Hormozgan, and Kohkilouye and Boyer Ahmad; Area 3: Provinces of Azarbayjan Sharqi, Azarbayjan Qarbi, Ardebil, Zanjan, Gilan, and Kordestan; Area 4: Provinces of Kermanshah, llam, Lorestan, Hamedan, Markazi, and Khouzestan; Area 5: Provinces of Khorasan Razavi, Khorasan Jonoubi, Khorasan Shomali, Kerman, Yazd, and Sistan and Balouchestan

imposing a high burden of care on the caregiver. In fact, due to the high level of impairment the patient experiences, the caregiver may feel more responsible to take care of the patient, therefore experiencing a higher level of stress and tension. This is in line with the findings of Steele and Covinsky [59, 60]. Due to the stigma surrounding seeking professional help for mental disorders in Iran, most caregivers may not be willing to talk about their mental problems. Therefore, this issue is expected to be more common than what is recorded $[61,62]$. The high level of burden of care in caregivers of patients with Alzheimer's disease can be related to deep dependence of these patients to their caregivers, which leads to different problems in the long term. The burden of care experienced by caregivers of these patients is so high that some researches consider the caregivers as hidden patients [63-65]. Patients with Alzheimer's disease are often old and their dependence and inability to care for themselves may lead to mental disorders in their caregivers. The symptoms of depression among these
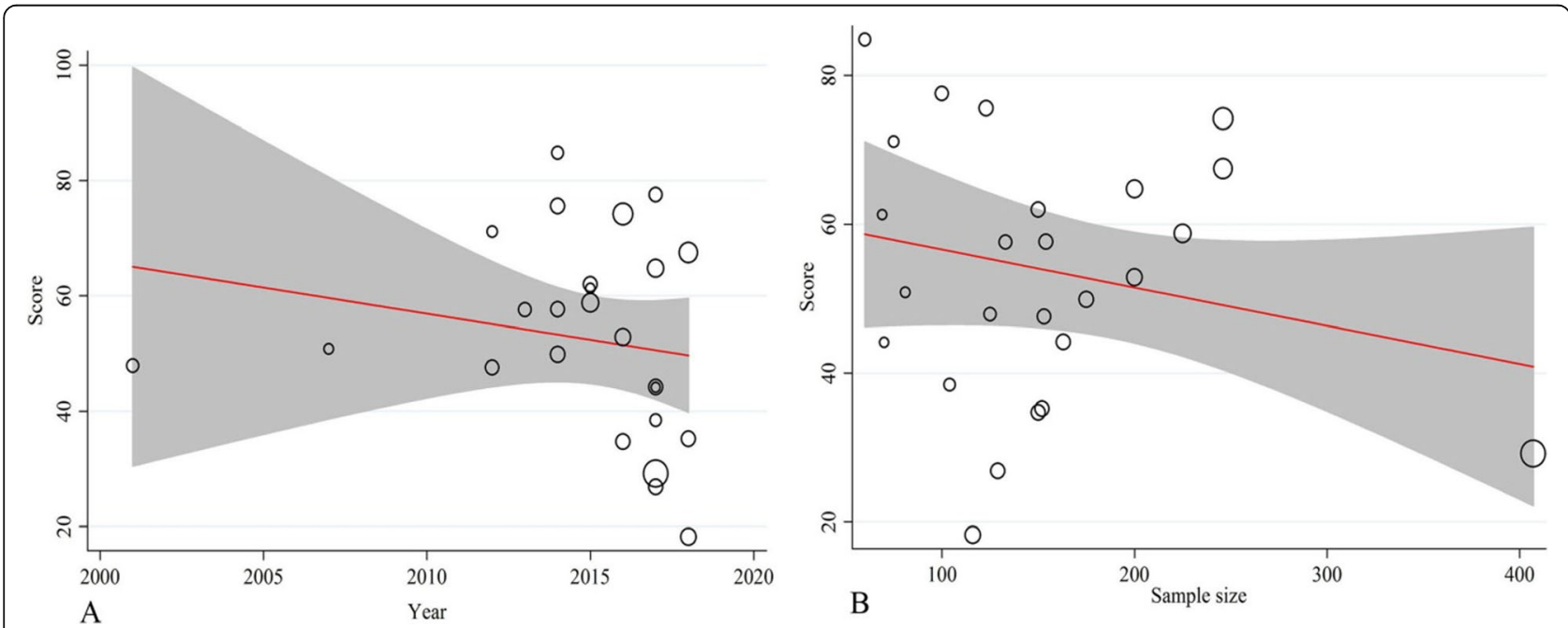

Fig. 3 Meta-regression of burden-of-care score (\%) versus year (A) and sample size (B). The circles show the weights of the studies 


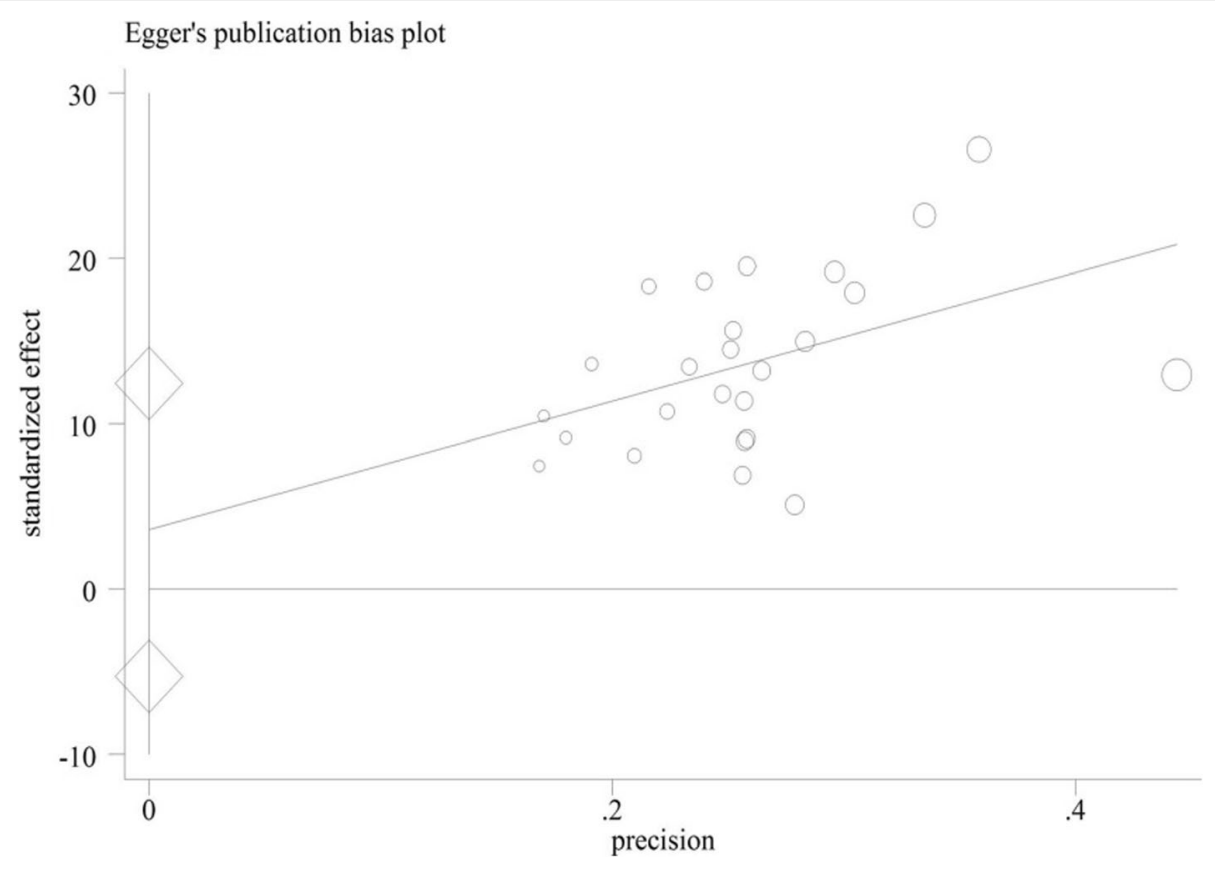

Fig. 4 Publication bias

caregivers are reported to be as twice as in other caregivers [65]. In Takai's study, caregivers of patients with Alzheimer's believed that caregiving had decreased their health and had made them vulnerable to fatigue and mental disorders [66].

In this research, patients with diabetes had the lowest burden of care score (\%). In line with this finding, in Kim's study that was focused on examining burden of care in caregivers of patients with cancer, mental disorders, Alzheimer's disease, diabetes, and other disorders, a higher burden of care was reported for patients with cancer and dementia compared to those with diabetes [67]. Based on previous studies conducted among patients with chronic disorders, those with diabetes have an average quality of life. It has been shown that patients with chronic disorders can become less dependent on their caregivers through self-care activities and controlling the symptoms of their illness $[68,69]$. This can reduce the burden of care faced by the caregiver.

The results of meta-regression analysis showed that between 2007 and 2018, there has been no change in the overall burden of care score (\%) of caregivers of Iranian patients with chronic disorders, although a decrease was expected in the score given the emergence of new methods of care. It appears that scientific methods are not implemented properly in many treatment centers across Iran, and caregivers of the patients may not receive adequate training. Therefore, caregivers bear a lot of pressure that may undermine their caregiving abilities over time. As a result of this, patients may need to seek help from treatment centers. One of the strengths of the present study is that for the first time, it has investigated and compared burden of care for caregivers of patients with chronic disorders in Iran. One of the limitations of the study was that grey literature (e.g. working papers, research reports, conference proceedings) was not included in the analysis, because there was no comprehensive database for grey literature in Iran. Another limitation was that some details, such as raw score of burden of care by gender had not been reported in the selected studies; this prevented further examination.

\section{Conclusion}

Caregivers of Iranian patients with Chronic disorders, especially those caring for patients undergoing dialysis, patients with mental disorders, and patients with Alzheimer's disease experience high levels of burden of care. Therefore, necessary measures need to be taken by Iranian health care officials to reduce burden of care in this group.

\section{Abbreviations}

CBI: Caregiver Burden Inventory; Cl: Confidence Interval; MCSI: Modified Caregiver Strain Index; PRISMA: Preferred Reporting Items for Systematic Reviews and Meta-Analyses; SID: Scientific Information Database; STROBE: Strengthening The Reporting of OBservational Studies in Epidemiology; ZBI: Zarit Caregiver Burden Interview

\section{Acknowledgements}

The authors appreciate all the researchers whose articles were used in the present research. 


\section{Availability of data and material}

The datasets used and/or analyzed during the current study are available from the corresponding author on reasonable request.

\section{Authors' contributions}

Reza Ghanei Gheshlagh and Hayedeh Rezaei: data collection; Hayedeh Rezaei: study design; Reza Ghanei Gheshlagh: final revision and grammar editing; Seyed Hassan Niksima: statistical analysis. The author(s) read and approved the final manuscript

\section{Funding}

None.

\section{Ethics approval and consent to participate}

Not applicable.

\section{Consent for publication}

Not applicable.

\section{Competing interests}

The authors declare that they have no competing interests.

\section{Author details}

${ }^{1}$ Department of Nursing. Faculty of Nursing and Midwifery, Kurdistan University of Medical Sciences, Sanandaj, Iran. ${ }^{2}$ Preventive Medicine and Public Health Research Center, Iran University of Medical Sciences, Tehran, Iran. ${ }^{3}$ Spiritual Health Research Center, Research Institute for Health Development, Kurdistan University of Medical Sciences, Sanandaj, Iran.

\section{Received: 13 June 2019 Accepted: 21 July 2020}

\section{Published online: 03 August 2020}

\section{References}

1. Tunstall-Pedoe H. Preventing Chronic Diseases. A Vital Investment: WHO Global Report. Geneva: World Health Organization; 2005. p. 200. Oxford University Press; 2006.

2. Livneh H, Antonak RF. Psychosocial adaptation to chronic illness and disability: a primer for counselors. Journal of Counseling \& Development 2005;83(1):12-20.

3. Faronbi JO, Faronbi GO, Ayamolowo SJ, Olaogun AA. Caring for the seniors with chronic illness: the lived experience of caregivers of older adults. Arch Gerontol Geriatr. 2019;82:8-14.

4. Buhler-Wilkerson K. Care of the chronically ill at home: an unresolved dilemma in health policy for the United States. The Milbank Quarterly. 2007; 85(4):611-39.

5. Amtmann D, Liljenquist KS, Bamer A, Gammaitoni AR, Aron CR, Galer BS, et al. Development and validation of the University of Washington caregiver stress and benefit scales for caregivers of children with or without serious health conditions. Qual Life Res. 2020:1-11.

6. Rodakowski J, Skidmore ER, Rogers JC, Schulz R. Role of social support in predicting caregiver burden. Arch Phys Med Rehabil. 2012:93(12):2229-36.

7. Möller-Leimkühler AM, Wiesheu A. Caregiver burden in chronic mental illness: the role of patient and caregiver characteristics. Eur Arch Psychiatry Clin Neurosci. 2012;262(2):157-66.

8. Dickson A, O'Brien G, Ward R, Flowers P, Allan D, O'Carroll R. Adjustment and coping in spousal caregivers following a traumatic spinal cord injury: an interpretative phenomenological analysis. J Health Psychol. 2012;17(2):247-57.

9. Grant M, Sun V, Fujinami R, Sidhu R, Otis-Green S, Juarez G, et al, editors. Family caregiver burden, skills preparedness, and quality of life in non-smallcell lung cancer. Oncology nursing forum; 2013: NIH Public Access.

10. Denno MS, Gillard PJ, Graham GD, DiBonaventura MD, Goren A, Varon SF, et al. Anxiety and depression associated with caregiver burden in caregiver of stroke survivors with spasticity. Arch Phys Med Rehabil. 2013:94(9):1731-6.

11. Mellon S, Northouse LL, Weiss LK. A population-based study of the quality of life of cancer survivors and their family caregivers. Cancer Nurs. 2006; 29(2):120-31.

12. Sawatzky J, Fowler-Kerry S. Impact of caregiving: listening to the voice of informal caregivers. J Psychiatr Ment Health Nurs. 2003;10(3):277-86.

13. Abbasi A, Ashraf-ebrahimi N, Asayesh H, Shariati A, Rahmani H, Mollaei E. Relationship between caregivers burden and counter skills in hemodialysis patient. Journal of Urmia Faculty of nursing and midwifery 2012;4(39):533-9. 2012:4(39):533-39.

14. Schulz R, Beach SR. Caregiving as a risk factor for mortality: the caregiver health effects study. Jama. 1999;282(23):2215-9.

15. Kiecolt-Glaser JK, Glaser R, Shuttleworth EC, Dyer CS, Ogrocki P. Speicher CE. Chronic stress and immunity in family caregivers of Alzheimer's disease victims. 1987;49(5):523-35.

16. Ghiasi F, Sangtarash F. The effect of stabilization method and Williams exercise on improvement of functions in patients with mechanical chronic low back pain \% journal of Shahrekord Uuniversity of medical sciences. Journal of Shahrekord Uuniversity of Medical Sciences 2007:8(4):21-28.

17. Milbury K, Badr H, Fossella F, Pisters KM, Carmack CL. Longitudinal associations between caregiver burden and patient and spouse distress in couples coping with lung cancer. Supportive care in cancer : official journal of the Multinational Association of Supportive Care in Cancer. 2013:21(9):2371-9.

18. * Talebi M, Mokhtari LN, Rezasoltani P, Kazemnejad LE, Shamsizadeh M. Caregiver burden in caregivers of renal patients under hemodialysis. Journal of Holistic Nursing And Midwifery. 2016;26(2):59-68.

19. * Salmani NAT, Hasanvand S. The burden of Caregiverand related Factorsof oncology. Advances in Nursing \& Midwifery. 2014;24(84):11-8.

20. Mohammed S, Priya S, George C. Caregiver burden in a community mental health program: a cross sectional study. Kerala Journal of Psychiatry. 2015; 28(1):26-33.

21. * Mashayekhi F, Pilevarzadeh M, Rafati F. The assessment of caregiver burden in caregivers of hemodialysis patients. Materia socio-medica. 2015; 27(5):333-8.

22. Palma E, Simonetti V, Franchelli P, Pavone D, Cicolini G. An observational study of family caregivers' quality of life caring for patients with a stoma. Gastroenterol Nurs. 2012;35(2):99-104

23. Goldzweig G, Merims S, Ganon R, Peretz T, Altman A. Baider LAoo. Informal caregiving to older cancer patients: preliminary research outcomes and implications. 2013;24(10):2635-40.

24. Adelman RD, Tmanova LL, Delgado D, Dion S, Lachs MS. Caregiver burden: a clinical ReviewCaregiver BurdenCaregiver burden. JAMA. 2014:311(10):1052-60.

25. Moher D, Liberati A, Tetzlaff J, Altman DG. Preferred reporting items for systematic reviews and meta-analyses: the PRISMA statement. Ann Intern Med. 2009;151(4):264-9.

26. WHOQOL-BREF. University of Washington Seattle, Washington United States of America, 1997.

27. Novak M, Guest C. Application of a multidimensional caregiver burden inventory. The Gerontologist. 1989;29(6):798-803.

28. Zarit SH, Reever KE, Bach-Peterson J. Relatives of the impaired elderly: correlates of feelings of burden. The Gerontologist. 1980;20(6):649-55.

29. * Mohamadi SF. Self-efficacy and caregiver strain in alzheimer's caregivers. Iranian Journal of Ageing. 2006;1(1):26-33.

30. Farrugia $\mathrm{M}$, Kirsch A. Application of the strengthening the reporting of observational studies in epidemiology (STROBE) statement to publications on endoscopic treatment for vesicoureteral reflux. J Pediatr Urol. 2017:13(3):320-5.

31. * Asadi P, Fereidooni-Moghadam M, Dashtbozorgi B, Masoudi R. Relationship between care burden and religious beliefs among family caregivers of mentally ill patients. J Relig Health. 2019;58(4):1125-34.

32. * Azimi Lolaty H, Ramezani A, Bastani F, Haghani H. Family caregivers burden and its related factors among iranian elderly psychiatric patients caregivers. Iranian Journal of Psychiatry and Behavioral Sciences. 2018:12(2).

33. * Adili D, Dehghani-Arani F. The relationship between caregiver's burden and patient's quality of life in women with breast cancer. Journal of Research in Psychological Health. 2018;10(2):30-9.

34. * Jafari H, Ebrahimi A, Aghaei A, Khatony AJBN. The relationship between care burden and quality of life in caregivers of hemodialysis patients. BMC Nephrol. 2018 November 12;19(1):321.

35. * Hassanzadeh F, Hojjati H. The relationship between resilience and care burden among parents of students with intellectual disability in Golestan Province, Iran, in 2016. J Res Rehabil Sci. 2017:12(5):252-8.

36. * Rahimi Naderi S, Zanjani SE, Mashouf S. Investigating the relationship between spiritual intelligence and emotional intelligence and the level of caregivers'burden of diabetic patients. Pharmacophore. 2017;8(6):1173674.

37. * Mirsoleymani SR, Rohani C, Matbouei M, Nasiri M, Vasli P. Predictors of caregiver burden in Iranian family caregivers of cancer patients. Journal of Education and Health Promotion. 2017:6:91-9.

38. * Torabi Chafjiri R, Navabi N, Shamsalinia A. Ghaffari FJCiia. The relationship between the spiritual attitude of the family caregivers of older patients with stroke and their burden. Clin Interv Aging. 2017;12:453-8. 
39. * Safaeian Z, Hejazi SS, Delavar E, Hoseini Azizi T, Haresabadi M. The relationship between caregiver burden, and depression, anxiety and stress in family caregivers of cancer patients referred to imam Reza Hospital in Bojnurd City. Iranian Journal of Psychiatric Nursing. 2017;5(3):7-14.

40. * Khazaeipour Z, Rezaei-Motlagh F, Ahmadipour E, Azarnia-Ghavam M, Mirzababaei A, Salimi N, et al. Burden of care in primary caregivers of individuals with spinal cord injury in Iran: its association with sociodemographic factors. Spinal Cord. 2017:55(6):595-600.

41. * Bamari F, Madarshahian F, Barzgar B. Reviews burden of caring caregivers of patients with type $\|$ diabetes referred to diabetes clinic in the city of Zabol. J Diabetes Nurs. 2016:4(2):59-67.

42. * Vahidi M, Mahdavi N, Asghari E, Ebrahimi H, Ziaei JE, Hosseinzadeh M, et al. Other side of breast cancer: factors associated with caregiver burden. Asian Nursing Research. 2016;10(3):201-6.

43. * Haghgoo A, Zoladl M, Afroughi S, Rahimian H, Mirzaee MS. Assessment of the burden on family caregivers of patients with mental disorders hospitalized in Shahid Rajai Hospital in Yasuj, 2016. Iranian Journal of Psychiatric Nursing. 2017;5(2).

44. * Hosseini SS. Alijanpoor agha Maleki M, Bastani F, Salehabadi S, Ghezelbash S. relationship between general health and burden in female caregivers of patients with Alzheimer disease. Quarterly Journal of Sabzevar University of Medical Sciences. 2015;21(6):1134-43.

45. * Shamsaei F, Cheraghi F, Bashirian S. Burden on family caregivers caring for patients with schizophrenia. Iran J Psychiatry. 2015;10(4):239.

46. * Mashayekhi F, Rafati S, Rafati F, Pilehvarzadeh M, Mohammadi-Sardo M. A study of caregiver burden in mothers with thalassemia children in Jiroft, 2013. Modern Care Journal. 2014;11(3).

47. * Garmabi M, Pourmohamadreza-Tajrishi M. The prediction of tolerance level of mothers with educable and intellectual disabled children based on their religious attitudes. J Social Welfare Social Welfare. 2014;13(51):151-65.

48. * Abbasi A, Shamsizadeh M, Asayesh H, Rahmani H, Hosseini S, Talebi M. The relationship between caregiver burden with coping strategies in family caregivers of cancer patients. Iranian Nursing Scientific Association. 2013; 1(3):62-71.

49. * Abdollahpour I, Noroozian M, Nedjat S, Majdzadeh R. Psychiatric symptoms in patients with dementia: prevalence and their relationship with caregiver burden. Iran J Epidemiol. 2012;4(2):51-9.

50. * Haresabadi M, Bibak B, Hosein ZE, Bayati M, Arki M, Akbari H. Assessing burden of family caregivers of patients with schizophrenia admitted in imam Reza hospital-Bojnurd 2010. Journal of North Khorasan University of Medical Sciences. 2012;2(12):165-72.

51. * Navidian A, Zaheden FB. Burden experienced by family caregivers of patients with mental disorders. Pak J Psychol Res. 2008;23(1):19-28.

52. Higgins JP, Thompson SG, Deeks JJ, Altman DG. Measuring inconsistency in meta-analyses. Bmj. 2003;327(7414):557-60.

53. Higgins JP, Green S. Cochrane handbook for systematic reviews of interventions: john Wiley \& sons; 2011.

54. Egger M, Smith GD, Schneider M, Minder C. Bias in meta-analysis detected by a simple, graphical test. Bmj. 1997;315(7109):629-34.

55. Etters L, Goodall D. Harrison BE. Caregiver burden among dementia patient caregivers: A review of the literature. 2008;20(8):423-8.

56. Bayoumi MM. Subjective burden on family carers of hemodialysis patients. Open Journal of Nephrology. 2014;2014

57. Mollaoğlu M, Kayataş M, Yürügen B. Effects on caregiver burden of education related to home care in patients undergoing hemodialysis. Hemodial Int. 2013;17(3):413-20.

58. Rioux J-P, Narayanan R, Chan CT. Caregiver burden among nocturnal home hemodialysis patients. Hemodial Int. 2012;16(2):214-9.

59. Covinsky KE, Newcomer R, Fox P, Wood J, Sands L, Dane K, et al. Patient and caregiver characteristics associated with depression in caregivers of patients with dementia. J Gen Intern Med. 2003;18(12):1006-14.

60. Steele A, Maruyama N, Galynker I. Psychiatric symptoms in caregivers of patients with bipolar disorder: A review. Journal of Affective Disorders. 2010 2010/02/01/:121(1):10-21.

61. Park S, Park KS. Family stigma: a concept analysis. Asian Nursing Research. 2014:8(3):165-71.

62. Mohamadi M, Mohtashami J. Arab Khangholi Z. Stigma towards patients with mental disorders Iranian Journal of Systematic Review in Medical Sciences. 2017;1(1):61-72.

63. Chiao $\mathrm{C}-\mathrm{Y}$, Wu H-S, Hsiao $\mathrm{C}-\mathrm{Y}$. Caregiver burden for informal caregivers of patients with dementia: a systematic review. Int Nurs Rev. 2015;62(3):340-50.
64. D'Onofrio G, Sancarlo D, Addante F, Ciccone F, Cascavilla L, Paris F, et al. Caregiver burden characterization in patients with Alzheimer's disease or vascular dementia. International Journal of Geriatric Psychiatry. 2015;30(9):891-9.

65. Takano M, Arai H. Gender difference and caregivers' burden in early-onset Alzheimer's disease. Psychogeriatrics. 2005;5(3):73-7.

66. Takai M, Takahashi M, Iwamitsu Y, Oishi S, Miyaoka H. Subjective experiences of family caregivers of patients with dementia as predictive factors of quality of life. Psychogeriatrics. 2011;11(2):98-104.

67. Kim Y, Schulz R. Family Caregivers' strains:comparative analysis of Cancer caregiving with dementia. Diabetes, and Frail Elderly Caregiving. 2008;20(5): 483-503.

68. Monjamed Z, Ali Asqharpoor M, Mehran A, Peimani T. The quality of life in diabetic patients with chronic complications. Hayat. 2006:12(1):55-66.

69. Rubin RR, Peyrot M. Quality of life and diabetes. 1999;15(3):205-18.

\section{Publisher's Note}

Springer Nature remains neutral with regard to jurisdictional claims in published maps and institutional affiliations.
Ready to submit your research? Choose BMC and benefit from:

- fast, convenient online submission

- thorough peer review by experienced researchers in your field

- rapid publication on acceptance

- support for research data, including large and complex data types

- gold Open Access which fosters wider collaboration and increased citations

- maximum visibility for your research: over $100 \mathrm{M}$ website views per year

At $\mathrm{BMC}$, research is always in progress.

Learn more biomedcentral.com/submissions 